\title{
GEO-STRATEGIC CONSEQUENCE OF CHABAHAR AND GWADAR SEA PORTS: AND THE INTERESTS OF EXTERNAL PLAYER
}

\author{
Mohammad Yousaf \\ Associate Professor (Political Science) \\ Education Department Colleges, Balochistan \\ Quetta - Pakistan \\ mohammadyousaf4477@gmail.com \\ Dr. Adil Zaman Kasi, \\ Professor Department of Political Science \\ University of Balochistan \\ Quetta - Pakistan \\ adilkasi@yahoo.com \\ Dr. Mulazim Hussain \\ Assistant Professor \\ Department of Political Science \\ Government Degree College Quetta \\ Quetta-Pakistan \\ mulazimhussainkhan42@gmail.com
}

\begin{abstract}
In this study, we are trying to examine the Geostrategic and economic potentials of Gwadar and Chabahar deep Sea ports recently two constructed ports while Gwadar situated in Balochistan Province of Pakistan and Chabahar located in Sistan and Balochistan area of Iran has been recognized as coagulated strategic agreements between China and Pakistan and between India and Iran. These sea port politics are forming an unbalance of powers in the region after the United States of America is expanding its military role in the region and attended more strategic partnership with India. Both ports could change the dynamics of regional politics, oceanic trades and transshipment, therefore, in this developing scenario both Gwadar and Chabahar Iranian port have taken a central stage in the current phase of international politics and have taken a unique geo- strategic and geo-political significance. Gwadar deep sea
\end{abstract}




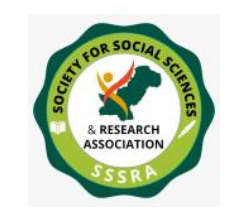

Pak. Journal of Int'L Affairs, Vol 4, Issue 3 (2021)

Geo-Strategic Consequence of Chabahar ...

port is weighted as a strategic base from where; China can monitor US movement in the Persian Gulf, Indians naval actions in the Arabian sea and US-Indo maritime cooperation in the IOR (Indian Ocean Region). India, in response of this strategic move developing Chahbahar port with Iranian assistances and partnership of Afghanistan, desire to Central Asian countries coupled with to reduce the influence of Chinas future long -run geo-economic and strategic interest in the entire region. The new economic, strategic and development move have created a new power structure which places the indigenous people better off after the new wave of globalization in this region. The development of Chabahar and more specifically Gwadar port could go nowhere, if the property rights of local masses and their socio economic security are not protected. One solution is to provide free and fair access of local masses to the new developments with equal distribution of resources and other opportunities to the locals at their doorsteps.

Keywords: External Powers, Geo-Strategic, Gwadar, Central Asia, Chabahar, China, Ports

\section{Introduction}

The sea politics is a complex phenomenon and getting more complex with an increase in worlds commercial activities. The water routes used for military interest have been transformed into economics, geopolitics, and strategic interest. Both cross country and other evidence show that access of many Asian countries to other parts of the world through their own land is very costly. Therefore, tend to search shortest possible route to link it with other countries. The greatest evidence is a rivals China and India. From Indian perspective, in recent, India has taken measures to reduce the value of CPEC route which singed between Sino-pakistan. Therefore, in this on going situation, one of the key initiatives taken by India is to build a deep water sea port at Chabahar in Iranian land. In 2003, Both Iran and India reached an agreement to execute this project, but this agreement was not feasible because of international sanction on Iran by Western Countries. As soon as these sanctions are over, Irans good weather friend, India is back to Iran and offered it to restart the 2003 agreement of building chabahar port. The two neighboring ports in Arabian Sea have taken a central position because of focal interest of the global leading countries like China, India, Iran, Pakistan, USA and Middle East to protect their long run Economic, Political, Geo-strategic, trade and naval-military powers in the Indian Ocean, Gulf of Oman. In present, the marine has been used as trade route since long and the modern trade to great extent enhanced the need of trade through sea routs. The current development of sea ports in Pakistan and Iran have opened the new 


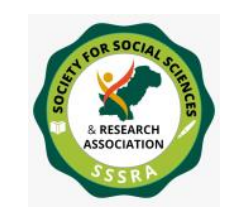

Geo-Strategic Consequence of Chabahar ...

economic and strategic rivalry between China and India, which could obstruct global shipping and may further deepen existing hostilities among these regional players. India, therefore, has the motives to desire the crumple of Gwadar project, if Gwadar project becomes unsuccessful, it would provide open space to Chahbahar; thus reduce Chinas potential to drain off Iranian and Gulf energy; furthermore it would refute the PLAN a naval garrison to control the Striate of Hormuz. Therefore, in this connection, Gwadar could become point of convergence for the destructive competition for energy and transit opportunities.

\section{Geo-Strategic Significance of Balochistan Gwadar Sea Port}

\section{LOCATION OF THE PORT}

Located on the doorstep of the oil-rich Middle East, Gwadar is assumed to be the strategic heart for the energy jugular from the energy-laden Central Asia especially for the energy-starved countries. Neighboring Strait of Hormuz is the world's most significant chokepoint with an estimated oil flow of seventeen million barrels oil per day in 2013, accounting around 30 of all seaborne-oil trade, whereas 85 of the crude oil to China, India, Japan and South Korea move through this bottleneck waterway (US Energy Information Administration, 2014). In 1960s, Pakistan's government realized the importance of Gwadar and started brainstorming for the construction of a seaport, but it could not materialize until 1991 when the first government of Nawaz Sharif decided to build a port in letter and in spirit (Azhar Ahmad, 2015). Due to political instability during the 1990s, no any self-styled democratic regime could turn its eyes towards this strategic pearl until 2001 when the military potentate General (R) Musharraf tendered China Harbour Engineering Company (CHEC) to develop a deep sea port onshore Makoran coast. Chinese assistance to develop Gwadar Port was a strategic move to sit astride the sea lines of communication starting off from the Hormuz Strait, which tick several boxes of the Chinese grand naval strategy, the String of Pearls (Dennis, Sanjay, 2015, pp.6365). China paid 75 of the .initial cost of US250 million for the construction of the port. The first phase completed in 2005 and inaugurated in 2007 remained dysfunctional due to the emergence of an armed conflict when the dynamics of regional politics changed after the tragic incident of 9/11 terrorist attacks and the US arrival in Afghanistan. In 2007 the Port of Singapore Authority (PSA) leased Gwadar Port for 40-years, but due to its paltry performance, the control of the port was handed over to China Overseas Port Holding Company (COPHC), a state-owned firm of China, the all-weather strategic comrade of Pakistan which received prompt reaction from then Indian Defense Minister A. K. Antony that China has strategic interests in a string of Indian Ocean ports to encircle India (Aymen Ajaz). 


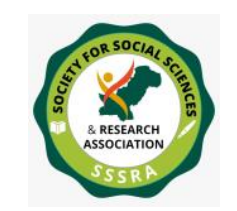

Pak. Journal of Int'L Affairs, Vol 4, Issue 3 (2021)

Geo-Strategic Consequence of Chabahar ...

\section{Strategic Significance of Gwardar}

Gwadar is strategically as well as economically important for China, due to various reasons to expand its maritime and economic clout in the region. The Chinese maritime route from the Persian Gulf to the disputed South China Sea through the Strait of Malacca -located between Indonesia, Malaysia and Singapore and connects eastern Indian Ocean to South China Sea and the western Pacific Ocean is around 12900 kilometers while Khunjerab mountain pass between Pakistan's Gilgit-Baltistan and Chinese Xinxiang region is only $3000 \mathrm{~km}$ away from Gwadar. After a hiatus of around 07 years, Gwadar Port seems to be simmering again after the ambitious initiative of the Chinese flagship project China-Pakistan Economic Corridor (CPEC) of US46 billion worth singed in April 2015 during an historic visit of the Chinese President Xi Jinping to Pakistan, which is the main jugular of the much talked-about Chinese One Belt One Road Initiative to revive its ancient commercial Silk Route (Zofeen T. Ebrahim, 2015). One Belt, One Road was unveiled by President $\mathrm{Xi}$ during his visits to Indonesia and Kazakhstan in 2013 to create an economic land belt by reviving the original Silk Road throughout Central Asia, Wet Asia, Middle East and Europe, and a maritime road to connect Chinese port facilities in Indian Ocean and on African Coast. This Chinese longterm initiative includes a series of road networks, railway lines, energy pipelines funded by Asian Infrastructure Idivestment Bank (AIIB) and New Silk Road Fund (Scott, David, 2015).

Tellingly, USA is not nave to the Chinese strategic and economic maneuverings in this region. Among the Pakistani policy-making circles, academia and media it is widely believed that besides India, the USA is also cajoling regional insurgents against China to counter the Chinese strategic calculation in this highly important region. The decade-old insurgency in Pakistan's largest but least developed province of Balochistan, the US failure to annihilate the festering Taliban insurgency in Afghanistan, the mushrooming role of Shanghai Cooperation Organization (SCO), strategic pursuit for energy security, oil politics and the Chinese escalating influence in Gwadar and adjacent areas are creating too much strategic uneasiness among the regional and extra-regional actors including the USA that solemnly wants to contain the emerging Chinese-led-Russianbacked strategic triangle with Pakistan in South and Central Asia (Sayed, 2007). Woodrow Wilson Center's senior fellow, Miachael Kugelman is of the opinion that US has planned its own Silk Route initiative which includes Turkey, Georgia, Azerbaijan, Turkmenistan, Uzbekistan, India and its Southeast Asian allies connecting to its main economic initiative in Asia-Pacific region, called Trans-Pacific Partnership (TPP).

Comparatively, China lacks vigorous maritime power and now it has realized the significance of the maritime power which is warranted for great power to be a 


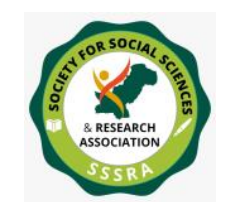

Geo-Strategic Consequence of Chabahar ...

superpower likewise the USA which controls the two largest oceans (Pacific and Atlantic) of the world with a strong military-cum. commercial presence in the Indian Ocean. Therefore, China has longtime intentions to invest in the maritime sector to comprehend its Indian Ocean naval doctrine by expanding it to the deep sea port of Gwadar. The Indian Ocean through which 80 of world's trade passes, is both strategically and commercially vital for both actors of the New Great Game as the well-known naval strategist, Alfred Mahan had said, "whosoever controls the Indian Ocean will dominate Asia", and the promising global market is Asia and Asia Pacific regions. The US strategic coalition with the India is judged to be the most imperative element in Pakistan's diplomatic maneuvering towards Sino-Russia bloc as India is austerely wary of the Chinese military maneuvering in the Indian Ocean especially its military base in Seychelles and surroundings (Guardian, 22 March, 2012).

\section{Geo Strategic Impotence of Chabahar}

Chabahar is a coastal county of Sistan and Balochestan and the southeastern port-city of Iran on the Gulf of Oman which gives Iran the direct access to the Indian Ocean. Situated on the Makoran Coast, this strategic port has been declared as a Free Trade and Industrial Zone by Iranian Government. The majority inhabitants of this port city speak Balochi and the word Chabahar has been derived from two Balochi word, char and Bahar (four springs) that mean all four seasons of the year are spring here. Back in the early 1970s, the Shah of Iran, Mohammad Reza Pahlavi intended to establish a modern maritime and air base to enhance the regional dominance of Iran, but owing to the Islamic Revolution of the late 1970s, this grand project was delayed until 2003, when India and Iran agreed to expand the port near Pakistan's border, but it made little progress due to the US and European sanctions on Iran (Reuters, May 5, 2015). After the diplomatic resolution of the contested Iranian nuclear program in July,2015(called P5+1 ) and the huge Chinese investment in Pakistan, India has accelerated to wind up the construction work of the port sooner than later which evidently manifest the Indian strategic aspirations too. The nuclear-related economic sanctions on Iran has cost around US160 billion in oil revenue since 2012 alone, but the sanctions have been lifted after the successful nuclear deal between Iran and P5+1 (USA, Britain, Russia, China, France + Germany) in mid-2015 that allowed Iran to get its more than US100 billion frozen overseas (Kasra, 2016).

There is a strategic as well as an economic reason behind the IndoIranian intimacy. Indian has strategic designs by constructing Chabahar Port to turn the strategic environment of the Indian Ocean in its favor for the purposing of befitting the paramount regional power, especially in the South Asian proximity and further seeks to be a global power (George, 200304, p. 129). On the other side India is the fastest growing economy 


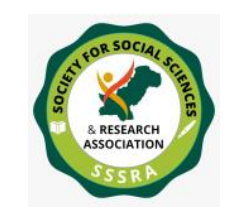

Pak. Journal of Int'L Affairs, Vol 4, Issue 3 (2021)

Geo-Strategic Consequence of Chabahar ...

along with China and world's sixth largest energy consumer and by 2020 it is prophesied to be the 4th largest consumer after the USA, China and Japan. Iran has world's third largest oil deposits estimated to be 132 billion barrels besides second largest proven gas reserves of 971 trillion cubic feet.

India has already spent one hundred million dollar on 220 kilometer Zaranj-Delaram Highway, completed in 2009, which connects Afghanistan's Nimroz Province with Farah and Herat and with Iranian frontier city of Zabol. Afghanistan lacks railway system, but there is effective railway connectivity in Iran and CARs. India has also promised US100 million for laying a railway line linking Afghanistan to Central Asia. In May 2015, India and Iran agreed on an MoU worth around US200 million for the development of Chabahar Port. India is also eyeing investing some additional 85 million dollars to fully operationalize cargo-container facilities at port that cost India around US23 million per annum (S. Mudassir, 2015). This connects the Chabahar Port on Makoran Coast to the Afghanistan's Ring Road connecting major cities of 16 out of 34 Afghan provinces like Kabul, Kandahar, Farah, Herat, Ghazni and Mazar-i-Asharif clockwise. This infrastructure development project was agreed in a trilateral meeting in January 2003. The Indian-funded communication infrastructure enables Afghanistan to access to the Arabian Sea via Iran by circumventing Pakistan (Ruhollah, 2016). According to Michael Kugelman, South Asian expert at the prestigious Woodrow Wilson Center, Afghanistan would benefit the most from this trilateral project as it gets access to other Middle Eastern and European markets. It would be an economic bonanza for war-ravaged economy of Afghanistan.

The Iranian Chabahar port would be the effective gateway to the Middle East and possibly Europe for the Central Asian and Afghanistan's exports. Poor infrastructure and limited connectivity has retarded the growth of the Afghan's war economy. Currently its exports only 570 million a year, while it imports 7.6 billion. Afghanistan's Chief Executive Officer Dr. Abdullah Abdullah visited Iran in January 2016 to finalize the Chabahar Transit and Transport Agreement. Consequently, it will result in devaluation of Pakistan's centrality as the Central Asian gateway and the only sea access to the landlocked Afghanistan, which could increase the existing 700-800 million bilateral trade with Iran to 3 billion a year (Sitwat, 2015). In Iran's north, a six hundred km long highway is already operational that link Chabahar to Zahiden, SistanBaluchestan capital, and from Zahiden to Milak near Afghan border it connects to the Zaranj border cross. A railway line from Chabahar to Zahiden is already under construction where it joins the Iranian network to Central Asia (Ayaz, 2015). Currently Chabahar Port is handling some 2-3 million tons of cargos per year, but by 2020, the port is designed to have the capacity to handle 80-82 million tons of cargos each year. India has also signed a US233 million 


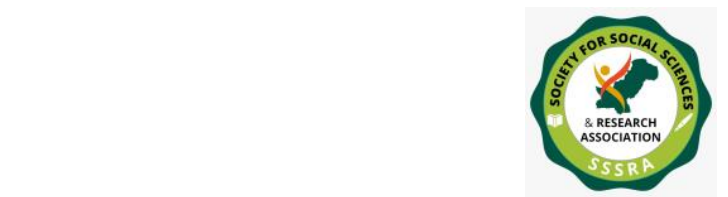

Geo-Strategic Consequence of Chabahar ...

contract to supply railway tracks to Iran besides investing 100 million in Iran's Farzad B gas field in 2008 (BBC, July 16, 2015).

India has considerable military and intelligence presence in Iran's coastal areas, especially the frontier regions along Pakistan. Indian consulates have been established in Zahiden and Bandar Abbas where India can easily conduct reconnaissance of the ship movements in the Persian Gulf and Gulf of Oman [2]. This ultimately enhances the Indian strategic ability to monitor Pakistan and clandestinely bolsters the low-level insurgency in the neighboring Balochistan inside Pakistan's border besides countering Pakistan's strategic interests in Afghanistan since Chabahar is considered to be the econo-strategic competitor of Pakistan's Gwadar Port. Despite of the US and Israeli (one of Indian largest arms suppliers) continued diplomatic pressure, India has never severed its economic and strategic relations with Iran even after securing a civilian nuclear deal with the US.

\section{Strategic Analysis of Both Ports Future}

The Chabahar and Gwadar sea Ports reflects India and Chinese keen interests in building vibrant trade links with landlocked Afghanistan, Central Asian Republics and beyond. Many strategic experts see Chabahar Port to be more significant to India than Iran because India can strategically access Afghanistan, Central Asia, Eurasia, Russia, Turkey and up to Northern Europe in addition to digging its foothold at the mouth of the strategic Strait of Hormuz at a distance of 76 nautical miles from the Chinese-controlled Gwadar Port. The Indian Ocean has world's busiest waterways and chokepoints from Southeast Asia to East Africa like the Strait of Malacca, Strait of Hormuz, Bab al-Mandeb and Suez Canal, connecting Europe (Qamar, Asma, 2015, p.73).

Simultaneously, Pakistan refuses to allow India to access Afghanistan; therefore Iran ticks all the boxes for Indo-Afghan connectivity. The geopolitical ramifications of a fully-functional Chabahar Port are overwhelming. It allows world's fourth largest energyconsumer, India, to access Iran's over 150 billion barrels crude oil and more or less 1,187 trillion cubic feet of gas deposits. Furthermore, the energy-starved India could access energy-rich Central Asia Republics' hydrocarbon resources, including Kazakhstan's 30 billion barrels of oil, 679,300 tons of uranium, and 37000 million tons of coal reserves and Turkmenistan's 265 trillion cubic feet gas reserves. The Chabahar Port facility would increase the India's currently meager trade with CARS.

Chinese companies are investing in the Iranian oil sector since the bilateral trade between the two anti-US-countries has hit the target of US53 billion in 2013 from 4 billion in 


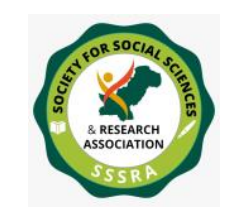

Geo-Strategic Consequence of Chabahar ...

2003. During the latest visit of the Chinese President in January this year, the two sides pledged to achieve a tradetarget of around US600 billion over the next decade in addition to signing 17 agreements worth of billions and forging a 25 -year strategic relation (Huileng, 2016).

Pakistan is quite uneasy over Indo-Iranian bourgeoning strategic and economic partnership and the Indian presence at the entrance of the Strait of Hormuz near its Gwadar Port. It looks as if India along with Iran and Afghanistan is strategically encircling Pakistan in the region based on the ancient Indian proverb that the enemy of my enemy is my friend. In such competing strategic circumstances, Pakistan needs to fence-mending charm offensive to normalize its often-conflicting relations with its western and southwestern Muslim neighbors besides being cognizant of the Indian strategic engagement with Iran and Afghanistan. Despite of being immediate neighbors and having railroad infrastructure connectivity, the Pak-Iran bilateral trade was recorded 893 million in 2014 that reached to a peak of US1.32 billion during 2008-09 while according to BBC regardless of crippling sanctions, Indo-Iranian bilateral trade was 14 billion in 2014 with the balance of trade heavily in Iranian favor.

Despite of the strategic divergence between Pak-Chinese and indo-Iranian regional blocs, these trade corridors could result into multiplication of regional trade and economic connectivity. The Indianled INSTC, Chineseled CPEC would further boost up intrregional and inter-regional connectivity among East Asia, South Asia middle east central Asia and possibly Eurasia besides the proposed lucrative ,Iran-Pakistan-India gaspipeline Turkmenistan-Afghanistan-Pakistan-India gas-pipeline (TAPI) and the central Asia-suth Asia electricity transmission and trade project (CASA-1000). for this purpose the already existing but dormant Malti-national regional forums like economic coordination Organizational (ECO) and Tehran-based Asian Clearing Union (ACU), linking central banks of the economic coordination and cooperation. Both china and India are the fastest-growing economies of world since the former is the second largest global economy while the latter is third largest Asian economy and their economy while the latter is third largest Asian economy and their presence in Gwader and Chabahar respectively should be based on economic cooperation and collaboration rather than strategic competition and confrontation the Chinese and Indian flagship infrastructure projects could also bring greater economic cohesion to worlds resource-rich but least economically integrated region of south Asia.

\section{Conclusion}




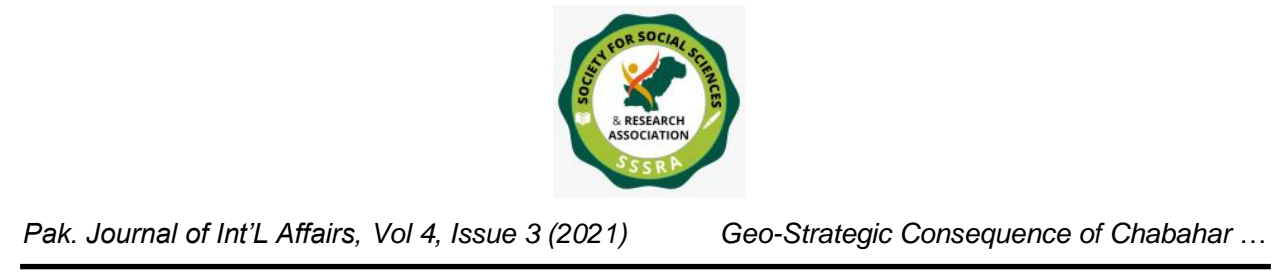

Geographically and Strategically both Gawadar and Chahbahr ports have equal logistic significance and to plays very significant role in shaping the changing dynamics of Asia and world politics. China, in recent years has increased its needs to energy due to its high economic growth. Therefore, the latest development in Gwadar port in term of ChinaPakistan Economic Corrodor (CEPEC) are the outcomes of this motives of China and voiced it returns to the Persian Gulf has induced new regional players as India. The concluding finding of this paper suggests for the smooth relations between regional and international players with their social economic and geo- politics interest after completion of both ports what will be the impacts on local masses. Iran, However, comparatively more developed with rich infrastructure to connect Chabahar with ACRs through Afghanistan as compare to Gwadar port under the CPEC project yet to develop and need to link with other developed parts of the country the role of two heavyweights in the region also analyze and in this research study recommendations proposals may be given. Therefore, it is argued in the ground of evidence that globalization through trade, mega projects, housing schemes, rural reforms and other development programs in this part of the world should serve the poorest of the community and the most vulnerable of the region that directly or indirectly depend upon agriculture sector and fisheries. The property rights of the local people should be protected at any level using every tool at government level. Hence Gwadar and Chabahar should be developed in a way to enhance the economic development of the country as well as the socio-economic development of the local population with the mean of equal distribution of resources. 


\section{References}

Ahmad, A. (2015) Gwadar: Potential and Prospects, Institute for Conflict and Security Studies Islamabad. http://www.picss.net/wp-content/uploads/2015/02/Dr-AzharGwadar-Potential:Prospects.pdf

Ahmed, A. (2015, October 11) Gwadar vs Chabahar, The News.

Ajaz, Aymen. (2015, August 20). Significance of Gwadar Port, IPRI, August 20, 2015. http://www.ipripak.org/significance-of-gwadar-port/\#sthash.TMoIKXZ5.dpbs

Aziz F., \& Hamal K.: a symbol of arousal, Bolan Voice, June 2013 Edition. https://bolanvoice.wordpress.com/2014/01/31/hamal-kalmati-a-symbol-of-arousal

Badalkhan, S. (2000). Portuguese encounters with coastal Makran Baloch during the sixteenth century. Some references from a Balochi heroic epic. Journal of the Royal Asiatic Society, 10(02), 153-169. doi:10.1017/s1356186300012438.

Badalkhan, S. (2009, September). Portuguese encounters with Makoran Baloch during the sixteen century, Vol.19, Issue 02, Royal Asiatic Society of Great Britain and Ireland, London: Cambridge University Press, September 2009, p.48.

Berlin, D. L. (2004). India-Iran Relations: A Deepening Entente. doi:10.21236/ada627491.

Berlin, D. L. (2004, October). India Iran Relations; A deepening Entente, Asia-Pacific Center for Security Studies Special Assessment. http://apcss.org/Publications/SAS/AsiaBilateralRelations/India$\underline{\text { IranRelationsBerlin.pdf }}$

Bokhari, S. W. (2015, July 25). Iran's Chabahar Port and the Strategic Turf War, ViewsWeek. http://wiewsweek.com/south-asia/palcistan/irans-chabahar-port-andthe-strategic-turf-wars/

Chinese plans in Seychelles revive Indian fears of encirclement. (2012, March 22). The Guardian. http://www.theguardian.com/world/2012/mar/22/china-seychellesindian-fears-encirclement

Decline in Afghan transit trade. (2013, April 29), Dawn. 
Ebrahim,, Z. T. (2015, April 20). China's new Silk road: What's in it for Pakistan, Dawn.

Fair, C. (2007; March 1.6). Indo-Iranian Ties: Thicker, than Oil. Nonproliferation Policy Education Center; http://www.npolicy.org,larticle,php?aid=270\&rtid=2

Fatima, Q., \& Asmam J., (2015, July-December) The Political and Economic Significance of Indian Ocean: An Analysis, South Asian Studies, Vol. 30, No.2, p. 73. http://pu.edu.pk/images/journal/csas/PDF/5\%20Qamir\%20Fatima_30_2.pdf

Fazal-e-Haider, S. (2007, January 15) Gwadar and Oil Politics, Dawn.

Haidari, M. Ashraf. (2015, Sept. 16) India and Afghanistan: A Growing Partnership, The Diplomat. $\quad$ http://thediplomat.com/2015/09/india-and-afghanistan-a-growingpartnership/

How Iran's nuclear deal affects India. (2045, July 16) BBC. http://www.bbc.com/news/world-asia-india733547061

Heydarian, R. J. (2014, 'March 11). South China Sea Dispute: The gloves are off, Aljazeera. http://www.aljazecra.com/indepthio-)inion/2014/03/sout-china-sea-di sputes-gloves-201431152920241884.html

India wants to deny Pakistan strategic depth in Afghanistan: US report. (2015, Nov. 04). Dawn.

India to sign port deal with Iran, Ignoring US • warning against haste. (2015, May 5). Reuters. http://www.reuters.com/articlelindia-iran-portidUSIANOXV16J20150505

India-Iran-Afghanistan transit corridor talks in progress: V K Singh.- (2016, March 02) The Economic Times. http://economictimes.indiatimes.com/news/politics-and nation/india-iran-afghani stan-transit-corridor-talks-in-progress-v-k$\underline{\text { singh/articleshow/51225529.ems }}$

Kennedy, S, \& David -A. P. (2015, April 03). Building China's "One Belt, One Road, Center for Strategic \& International Studies. htttp://csis.org/publication/buildingchinas-one-belt-one-road/ 
Khan, M. I. (2015; May 06) What lies' behind Pakistan. charges • of. India Terrorism, BBC. http://www.bbc.cornineWs/World-asia-32604137

Kugelman, M. (2015, May 08). Examining the implications of the Indo-Iranian Chabahar port deal, Deutsche Welle (DW) http://wwvv.dw.com/en/examining-theimplications-of-the-indo-iranian-chabahar-port-deal/a-18439937

R. M. (2012). Chinese plans in Seychelles revive Indian fears of encirclement. The Guardian, 22 